\title{
Burrowing Avoidance Assays of Contaminated Detroit River Sediments, Using the Freshwater Oligochaete Stylodrilus heringianus (Lumbriculidae)
}

\author{
David S. White ${ }^{1}$ and Timothy J. Keilty \\ Great Lakes Research Division Benthos Laboratory, 1061 North University Building, University of Michigan, \\ Ann Arbor, Michigan 48109
}

\begin{abstract}
The burrowing behavior of Stylodrilus heringianus (Lumbriculidae, Oligochaeta) was examined in bioassays, using sediments from suspected areas of contamination in the Detroit River, Michigan (U.S.A.). In assays with control sediments and sediments from a clean Detroit River site, all worms quickly burrowed $(<1 \mathrm{hr})$ and appeared to feed normally over a $96-\mathrm{hr}$ period. In sediments with suspected sediment-bound contaminants, Stylodrilus initially burrowed but returned to the surface after a few hours, the time of return apparently dependent on the degree of contamination and length of exposure. The presence of volatile contaminants reduced the initial burrowing response. These observations enhance the possibility of using a Stylodrilus burrowing behavior assay to aid in examining suspected areas of sediment contamination in the Great Lakes.
\end{abstract}

A variety of bioassays are now widely used for estimating the toxicity of effluents, receiving waters, and elutriates (e.g., Microtox ${ }^{\mathrm{TM}}$, Bulich and Isenberg 1981; Ceriodaphnia, Mount and Norberg 1984; Selenastrum capricornutum, Miller et al. 1978). However, few assays have been created which assess the effects and potential toxicity of in-place sediment contamination, particularly freshwater sediment contamination and its relationship to the macrozoobenthos community (White 1988).

Keilty et al. (1988) recently have described a short-term sediment lethality and avoidance assay using the freshwater aquatic earthworm Stylodrilus heringianus (Lumbriculidae). The Stylodrilus assay

\footnotetext{
${ }^{1}$ To whom correspondence should be addressed.
}

has been used primarily to assess the toxicity of a single sediment-bound compound (endrin) and has not been evaluated as an environmental monitor. Stylodrilus heringianus would appear appropriate for environmental assessment of sediment contamination because of its intimate interactions with sediment and because its burrowing behaviors have been quantified and described in detail (Robbins et al. 1984; White et al. 1987). Further, Stylodrilus is the dominant deposit feeding oligochaete of oligotrophic sediments in many northern lakes, especially the Laurentian Great Lakes (Lauritsen et al. 1985 ) where a variety of sediment contaminants exist.

The main objectives of the study were to examine the potential usefulness and sensitivity of the Stylodrilus sediment bioassay and to describe Stylodrilus behavior patterns in relation to contamination in natural sediments. In this paper, we present assay results, using sediments from four areas of suspected contamination in the Detroit River. Because bioassays by definition are endpoints in themselves (Mount and Norberg 1984), we have attempted to relate the results only to general sediment quality and not to specific sediment structure and chemistry. Deposits along the Detroit River are known to contain a vast array of potentially toxic substances from one of the largest industrial complexes in the world (Chau et al. 1985).

\section{Materials and Methods}

Control sediments and Stylodrilus heringianus were collected from a Lake Michigan depositional area approximately $10 \mathrm{~km}$ offshore from Bridgman, Michigan, using a PONAR grab. Water depth was $42 \mathrm{~m}$. Sediments were fine sand with fine-grained silts and clays (Robbins et al. 1984). This site has been described in 
detail by White et al. (1986a, 1986b). The dominant oligochaete was the oligotrophic Stylodrilus heringianus, which occurs throughout much of Lake Michigan's deep depositional areas (Lauritsen et al. 1985). Sediments and Stylodrilus, with Lake Michigan water, were maintained in a darkened $200 \mathrm{~L}$ aquarium at $10^{\circ} \mathrm{C}$ for several months prior to experimental use. Acclimation of at least one month has been recommended by Keilty (1987).

Detroit River sediments were collected with a PONAR grab at four sites (Figure 1, Table 1), at least three of which (Stations 30, 34 , and 53) were suspected to contain a variety of contaminants (Chau et al. 1985). Sediments were placed in acid-cleaned glass jars, capped in the field, and kept refrigerated $\left(1^{\circ} \mathrm{C}\right)$ in the laboratory. Water also was collected at each site $0.5 \mathrm{~m}$ off the bottom and kept refrigerated until used. Tests were run within $48 \mathrm{hr}$ of collection.

Bioassay procedures followed those outlined by Keilty et al. (1988). In all assays, approximately $25 \mathrm{ml}$ wet sediment (gently stirred but not sieved) were spooned into $50-\mathrm{ml}$ beakers, and any visible oligochaetes were removed. In the first assay, five replicates were created for each of the four experimental sediments and for the Lake Michigan control sediment. Twenty to $25 \mathrm{ml}$ of matching river or control water (overlying Lake Michigan aquarium water) was gently pipetted into each beaker to limit sediment resuspension. Prepared beakers were placed into an environmental chamber at $10^{\circ} \mathrm{C}$, the temperature of the Detroit River at the time of field collections.

Control sediments containing Stylodrilus were gently sieved $(0.5 \mathrm{~mm}$ mesh) to concentrate worms. A fiber-optic light (to prevent unnecessary heating) and a dissecting microscope were used to sort and identify Stylodrilus. Ten large (20-30 $\mathrm{mm}$ long) Stylodrilus were added to each beaker. Stylodrilus were added individually to reduce the formation of 'balls' making initial burrowing observations easier (Keilty et al. 1988).

Burrowing and visual 'health' observations were made at 0.17 , $0.5,1,2,4,8,12,24,48,72$, and $96 \mathrm{hr}$. A worm was considered unburrowed if more than an estimated $75 \%$ of its body was exposed on the sediment surface. Healthy unburrowed Stylodrilus were very active and appeared bright red. Death was defined as an absence of any red coloration (yellow to clear), no response to touch, and an unmistakable degree of body degeneration. At the end of $96 \mathrm{hr}$, the contents of each beaker was sieved $(0.5 \mathrm{~mm}$ mesh) to determine the number and health of Stylodrilus remaining in the sediment.

Beakers were not covered during the assays to allow natural gas exchange. Dissolved oxygen concentrations in the overlying waters were measured at $0,12,48$, and $96 \mathrm{hr}$, using a YSI Model 57A Dissolved Oxygen meter. Dissolved oxygen decreased very slowly in all beakers over the 96 -hr period to between $70-80 \%$ saturation. As these dissolved oxygen levels should not cause stress to Stylodrilus (Robbins et al. 1984), water in the beakers was not aerated.

In the second assay, Station 34 sediments were diluted with control sediments. Concentrations were 0 (control), 2, 10, 50, and $100 \%$ Station 34 sediment (v:v). Each concentration contained five replicates, and assays followed the protocol given above. A 96-hr $\mathrm{LC}_{50}$ determination was made by the LitchfieldWilcoxon nomographic method (Litchfield and Wilcoxon 1949).

In the third assay, Station 34 sediments were air-dried in an attempt to reduce any volatile contaminants. After drying at room temperature for approximately $96 \mathrm{hr}$, sediments were rewetted with Station 34 water, gently mixed, and added to four, $50 \mathrm{ml}$ beakers. Assays again followed the protocol given above, except that no additional controls were run.

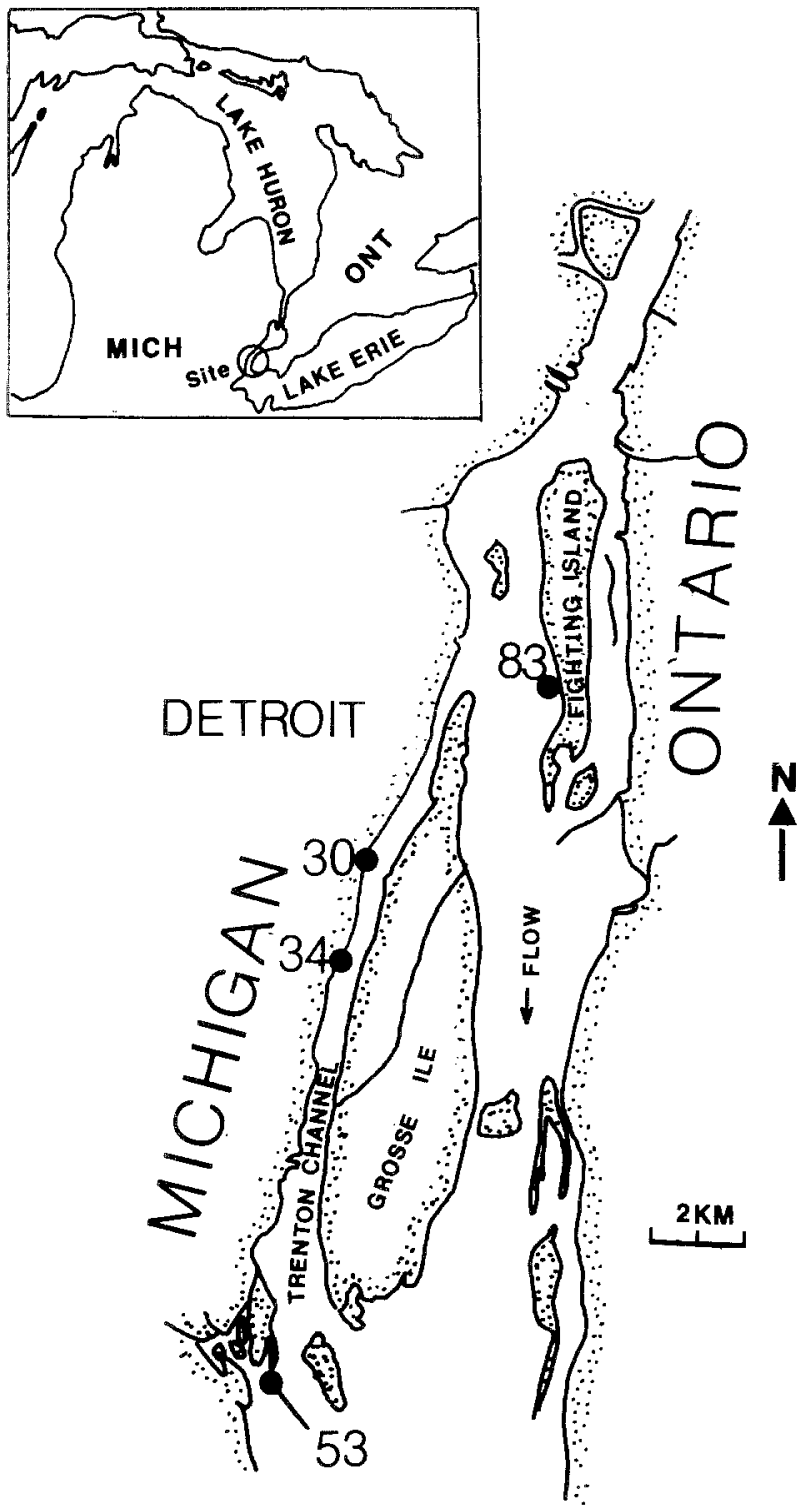

Fig. 1. Map of lower Detroit River showing station locations

\section{Results and Discussion}

\section{Detroit River Sediment Assays}

Control sediments were typical of off-shore depositional areas in the Great Lakes in being odor-free and containing primarily fine sands and clay with a mixture of various sizes of organic particles (Robbins et al. 1984). Although thorough particle analyses have not been completed for the test sediments, some preliminary particle size ranges and qualitative assessments are listed in Table 1. All Detroit River sediments contained some sands and clays. The most variable component was the amount of organic material, which was reflected in 
Table 1. Collection location and selected sediment characteristics of control and Detroit River stations. Percent of particles $>0.025 \mathrm{~mm}$ and $>0.063 \mathrm{~mm}$ by weight and \% total organic carbon (TOC) by weight from an unpublished report by J. DePinto, Clarkson University

\begin{tabular}{|c|c|c|c|c|}
\hline $\begin{array}{l}\text { Station } \\
\text { No. }\end{array}$ & $\begin{array}{l}\text { Latitude/ } \\
\text { longitude }\end{array}$ & $\begin{array}{l}\text { Sediment description } \\
\text { and composition } \\
(>0.250>0.063 \mathrm{TOC})\end{array}$ & Color & $\begin{array}{l}\text { Odor at time } \\
\text { of collection }\end{array}$ \\
\hline 30 & $\begin{array}{l}42^{\circ} 10^{\prime} 19^{\prime \prime} \\
83^{\circ} 09^{\prime} 56^{\prime \prime}\end{array}$ & $\begin{array}{l}\text { Silt and fine organic particles with } \\
\text { some larger organic debris } \\
(8.328 .99 .3)\end{array}$ & Dark brown & Strong hydrocarbon \\
\hline 34 & $\begin{array}{l}42^{\circ} 08^{\prime} 51^{\prime \prime} \\
83^{\circ} 10^{\prime} 24^{\prime \prime}\end{array}$ & $\begin{array}{l}\text { Silt and fine organic particles } \\
(1.23 .110 .0)\end{array}$ & Black & Very strong hydrocarbon \\
\hline 53 & $\begin{array}{l}42^{\circ} 04^{\prime} 48^{\prime \prime} \\
83^{\circ} 11^{\prime} 34^{\prime \prime}\end{array}$ & $\begin{array}{l}\text { Silty sand with some fine organic } \\
\text { particles } \\
(4.016 .94 .8)\end{array}$ & Brown & Very mild hydrocarbon \\
\hline 83 & $\begin{array}{l}42^{\circ} 12^{\prime} 42^{\prime \prime} \\
83^{\circ} 07^{\prime} 31^{\prime \prime}\end{array}$ & $\begin{array}{l}\text { Sandy clay with very few organic } \\
\text { particles } \\
(3.512 .02 .5)\end{array}$ & Yellow-brown & No odor \\
\hline Control & $\begin{array}{l}42^{\circ} 00^{\prime} 81^{\prime \prime} \\
86^{\circ} 44^{\prime} 12^{\prime \prime}\end{array}$ & $\begin{array}{l}\text { Sandy silt with some fine organic } \\
\text { particles } \\
(4.320 .23 .3)\end{array}$ & Brown & No odor \\
\hline
\end{tabular}

total organic carbon contents that ranged from $2.5 \%$ at Station 83 to $10 \%$ at Station 34. Sediment compaction was not measured during the assays, but it was not significant enough to have affected burrowing.

In both sets of controls (first and second assays), Stylodrilus quickly burrowed and remained burrowed through the 96-hr period (Figures 2 and 7). Most Stylodrilus were in the sediment within 0.17 $\mathrm{hr}$, and 99 of $100 \mathrm{had}$ burrowed after $2 \mathrm{hr}$. Only one worm in the first control set (Figure 2) did not burrow, and it remained alive on the surface throughout the assay. Other Stylodrilus occasionally were noted on the surface, but the mean number of unburrowed Stylodrilus per replicate was always less than 1.0. There were no mortalities.

Station 83 was located on the west side of Fighting Island (Figure 1) in an area of the Detroit River thought to be away and upstream from most of the more severe areas of contamination (Chau et al. 1985). Sediments contained a much greater proportion of larger clay particles than at other test sites or in control sediments. Sediments had no unusual odor at the time of collection (Table 1) or during the assays. Even though high proportions of clay are not typical of the normal Stylodrilus habitat (LaDronka 1984), all except one worm had burrowed within one $\mathrm{hr}$, and a mean of less than 1.0 worms per replicate were on the surface at any one time over $96 \mathrm{hr}$ (Figure 3). One death was recorded at $72 \mathrm{hr}$.

Station 53 was near the mouth of the Detroit River in an area strongly influenced by Lake Erie currents and wave action (Figure 1). Sediments were expected to contain at least some heavy metals, particularly zinc and chromium (Mudroch 1985; Hamdy and Post 1985) and possibly some organic contamination (Oliver and Bourbonniere 1985; Comba and Kaiser 1985). There were no hydrocarbon odors at the time of collection or during laboratory tests. Similar to control and Station 83 burrowing patterns, a mean of more than 8.0 Stylodrilus per replicate had burrowed after $0.17 \mathrm{hr}$, and all worms had burrowed after one hr (Figure 4). However, by $24 \mathrm{hr}$, a mean of 0.8 worms had returned to the sediment surface, and by $96 \mathrm{hr}$, the number of unburrowed Stylodrilus had increased to a mean of 2.2 , showing a moderate behavioral response to some component in the sediment. No mortalities occurred in any of the Station 53 replicates.

Station 30 was located in a depositional area along the west bank of the Trenton Channel. Sediments were suspected of containing a wide variety of metals, chlorinated hydrocarbons, and volatiles (Mudroch 1985; Hamdy and Post 1985; Oliver and Bourbonniere 1985; Comba and Kaiser 1985) and possibly some additional enrichment from the Detroit sewage treatment plant. Sediments were dark and 'oily', and there were distinct hydrocarbon odors during collection and laboratory tests. Stylodrilus did not burrow as quickly as in the controls, Station 53, or Station 83 sediments. Through $24 \mathrm{hr}$, a mean of 1.0 per replicate remained unburrowed (Figure 5). Between 24 and $48 \mathrm{hr}$, the mean number of unburrowed Stylodrilus per replicate increased to 3.4 and increased to 3.8 by $96 \mathrm{hr}$. A mean of 1.2 Stylodrilus per replicate were dead at the end of $96 \mathrm{hr}$. 


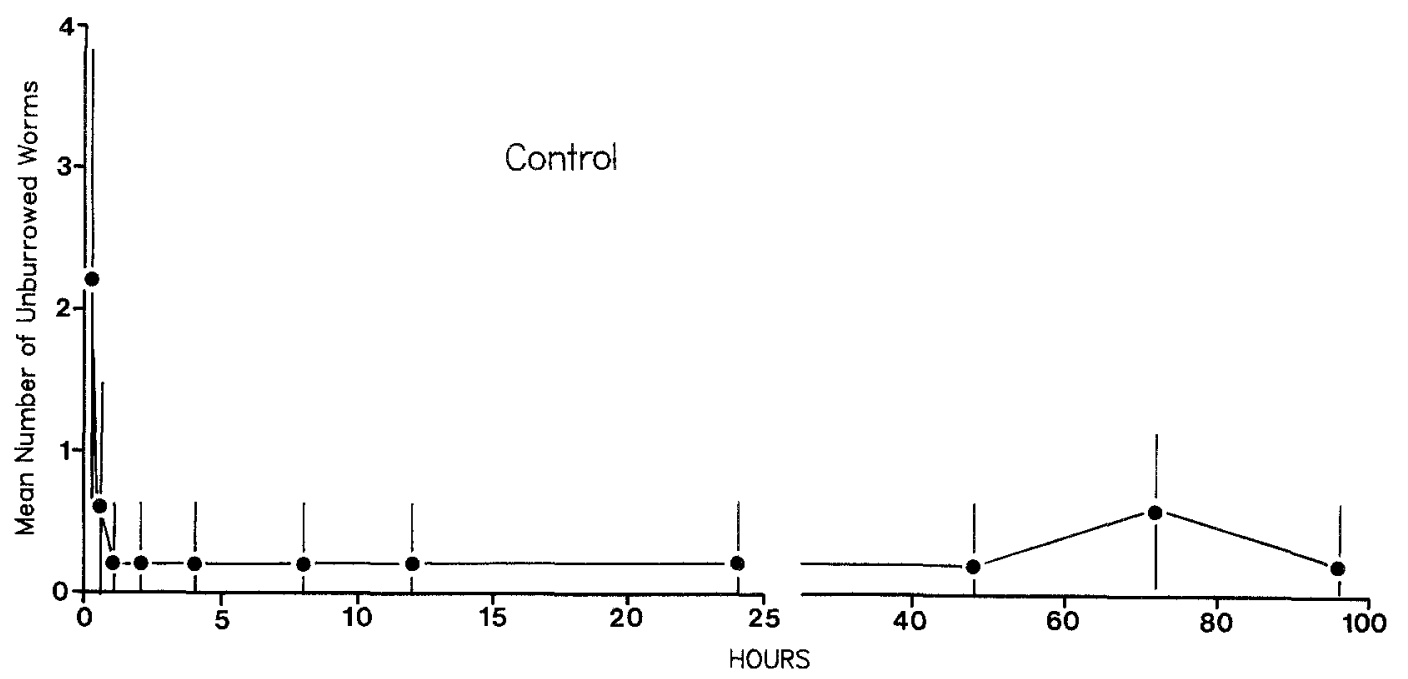

Fig. 2. Mean number and standard error of unburrowed Stylodrilus over time in the 96-hr assay using Lake Michigan (control) sediments, 5 replicates, 10 worms per replicate
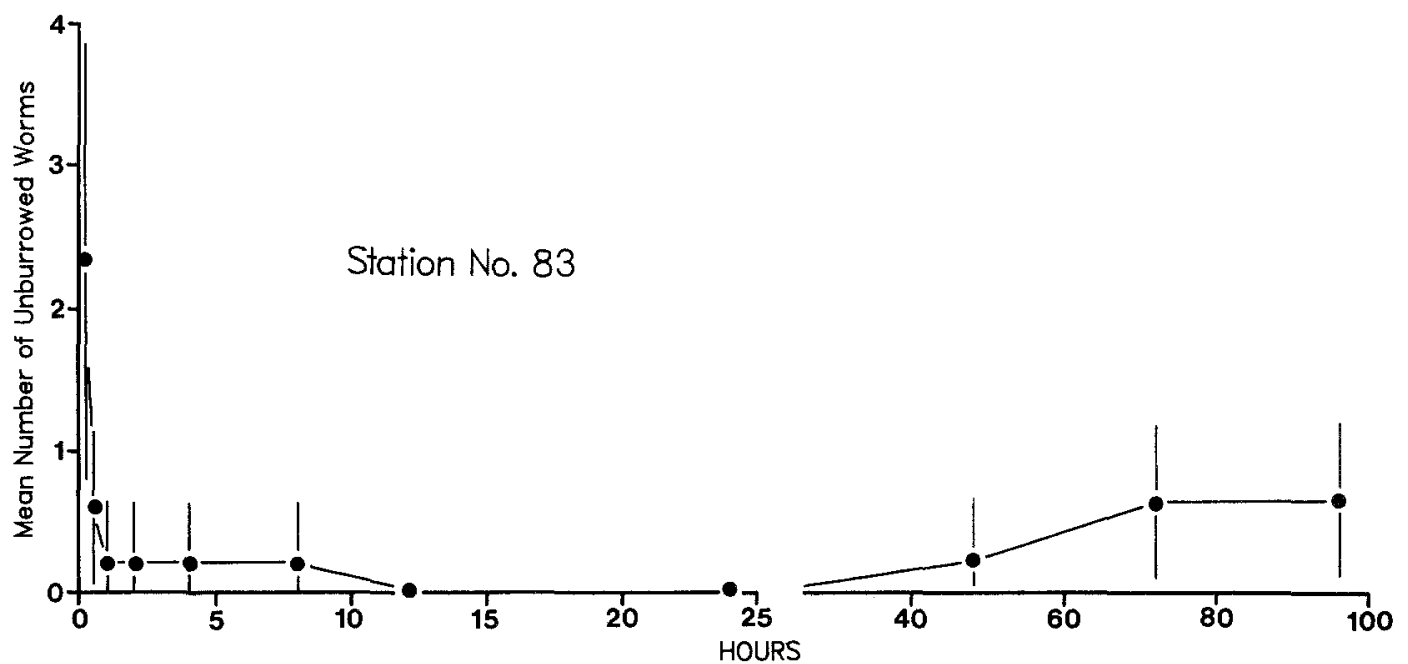

Fig. 3. Mean number and standard error of unburrowed Stylodrilus over time in the 96-hr assay using sediment from Detroit River Station 83,5 replicates, 10 worms per replicate

Similar to Station 30 , Station 34 was located in a large backwater area along the western shore of the Trenton Channel. Station 34 sediments were suspected to be the most contaminated of the four sites with potentially high levels of metals, chlorinated hydrocarbons, and volatiles (Mudroch 1985; Hamdy and Post 1985; Oliver and Bourbonniere 1985; Comba and Kaiser 1985). The hydrocarbon odor was very strong at the time of collection and during laboratory tests. A mean of only 3.6 Stylodrilus per replicate initially burrowed, and between 12 and $96 \mathrm{hr}$, a mean of 7.6 worms were on the sediment surface (Figure 6). After $24 \mathrm{hr}$, most Stylodrilus on the surface had lost their distinctive red pigmentation and appeared very unhealthy. After $48 \mathrm{hr}$, a mean of 7.8 of the Stylodrilus on the surface were dead; after $96 \mathrm{hr}$, a mean of only 0.6 Stylodrilus per replicate were alive (two of the original 50 worms were on the surface, and one was buried in the sediment).

\section{Station 34 Sediment Dilution and Drying Assays}

In addition to burrowing observations, the dilution series allowed a 96-hr $\mathrm{LC}_{50}$ estimate for Station 34 sediments. Results of the control and $100 \%$ Station 34 sediment concentration tests did not differ from 


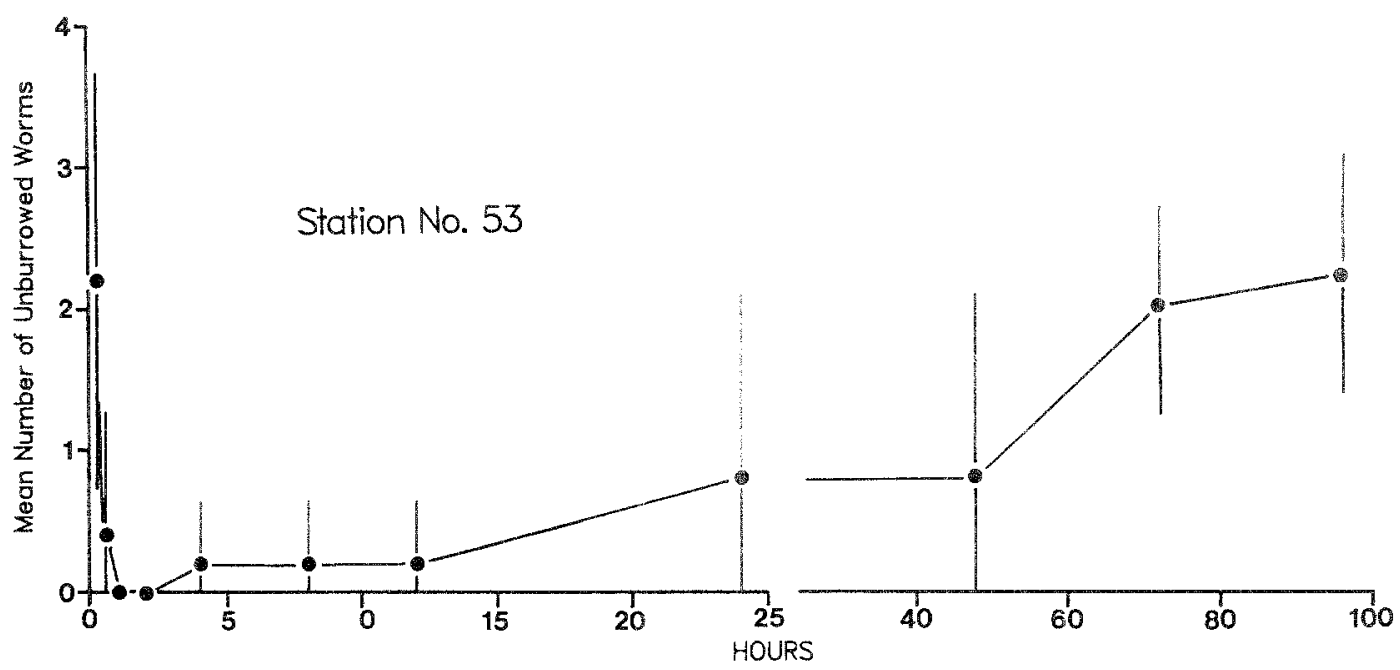

Fig. 4. Mean number and standard error of unburrowed Stylodrilus over time in the 96-hr assay using sediment from Detroit River Station 53, 5 replicates, 10 worms per replicate

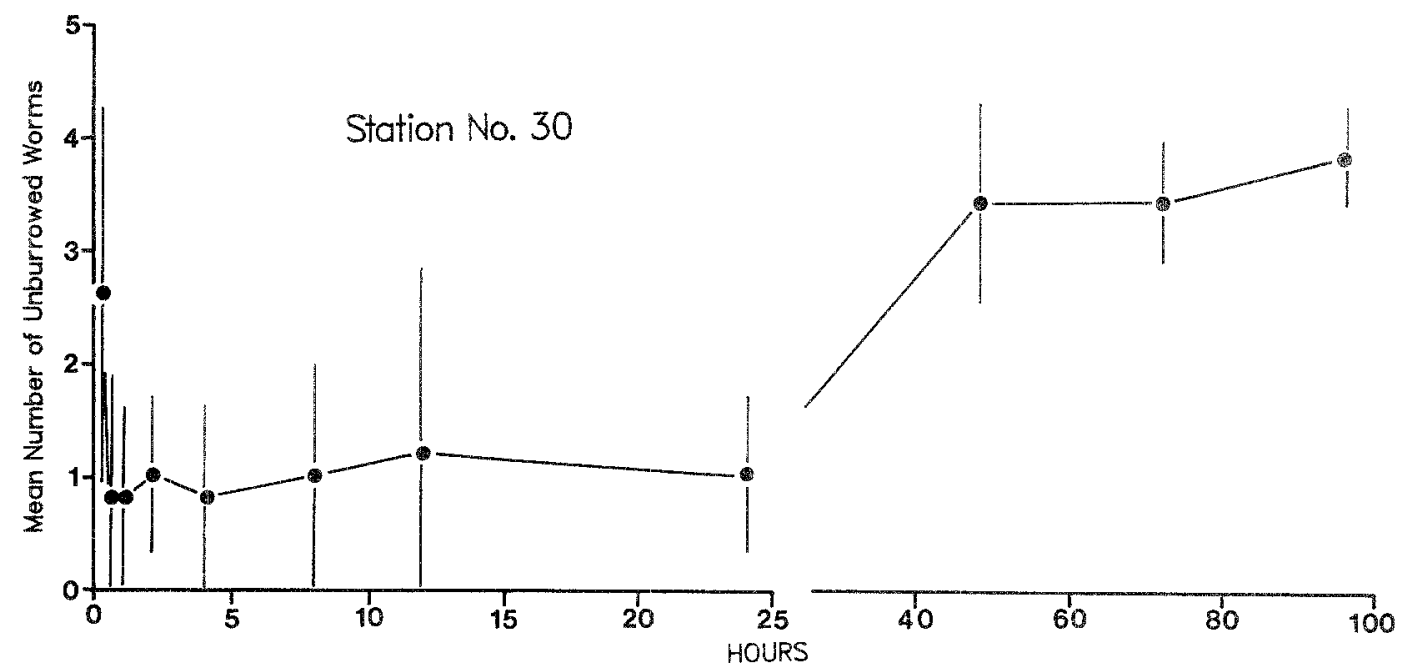

Fig. 5. Mean number and standard error of unburrowed Stylodrilus over time in the 96-hr assay using sediment from Detroit River Station 30,5 replicates, 10 worms per replicate

results in the first assays (Figure 7, see also Figures 2 and 6 ). In the $100 \%$ concentration, less than 2.0 Stylodrilus per replicate ever burrowed. A mean of 6.6 of the Stylodrilus on the surface were dead after $48 \mathrm{hr}$, and a mean of 8.4 of the total number of worms per replicate were dead after $96 \mathrm{hr}$.

Burrowing activities were normal in the $2 \%$ and $10 \%$ concentrations (Figure 7). A mean of 0.4 Stylodrilus per replicate died in the $2 \%$ mixture, and a mean of 0.6 died in the $10 \%$ mixture. In the $50 \%$ mixture, a mean of 5.6 had burrowed after two hr. After eight hr, a mean of 6.6 Stylodrilus were on the surface and many were yellowish. Surprisingly, a mean of 7.0 Stylodrilus per replicate were bur- rowed by the end of $12 \mathrm{hr}$, and most remained in the sediment through $96 \mathrm{hr}$. Four of 16 Stylodrilus on the surface at the end of $48 \mathrm{hr}$ were dead, and mean mortality after $96 \mathrm{hr}$ was 3.8 . The $96-\mathrm{hr} \mathrm{LC}_{50}$ calculated from these data was approximately equal to a 62\% Station 34 sediment concentration (Figure 8).

After air-drying and rewetting the Station 34 sample, sediments were lighter in color, and there were no obvious hydrocarbon odors. Subsequent initial burrowing responses were similar to responses observed in uncontaminated sediments. All Stylodrilus had burrowed after four hr (Figure 9). Similarly, after eight hr, only one of 40 Stylodrilus was on the surface, yet an additional $13 \mathrm{Sty}$ - 


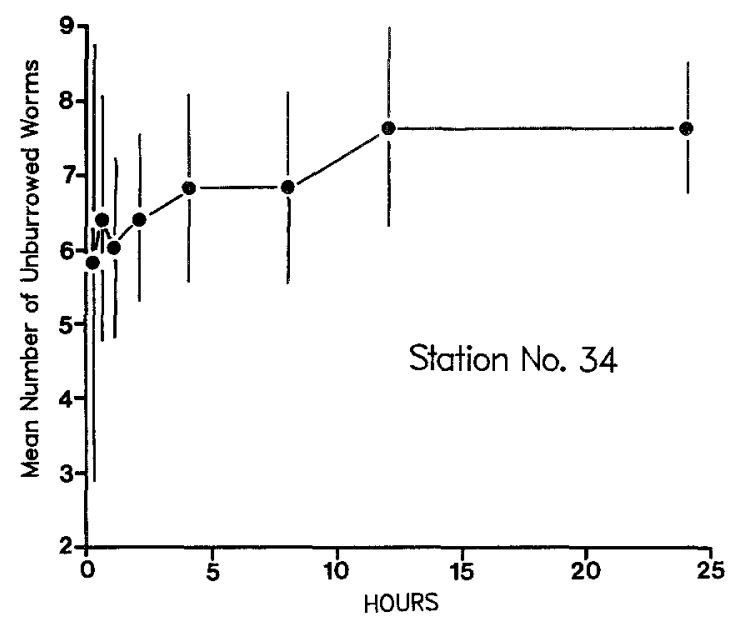

Fig. 6. Mean number and standard error of unburrowed Stylodrilus over time in the $96-\mathrm{hr}$ assay using sediment from Detroit River Station 34, 5 replicates, 10 worms per replicate. Points between 24 and $96 \mathrm{hr}$ equal to $24 \mathrm{hr}$ value and are not plotted

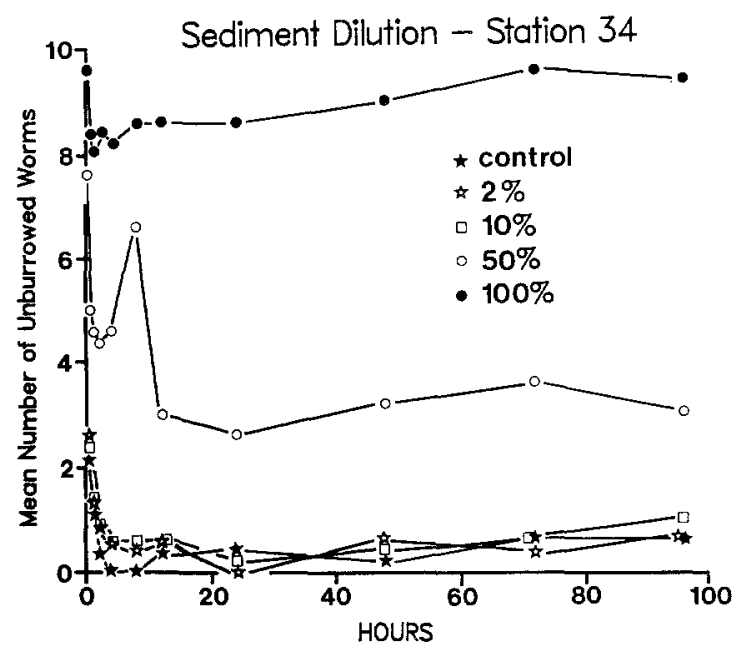

Fig. 7. Mean number of unburrowed Stylodrilus over time in a 96-hr assay using various mixtures (v:v) of Station 34 sediment diluted with Lake Michigan (control) sediment, 5 replicates, 10 worms per replicate

lodrilus were partially exposed $(<25 \%$ of body length) on the surface. After $24 \mathrm{hr}$, a mean of 4.5 Stylodrilus were totally exposed on the surface. Several Stylodrilus looked unhealthy, but none had died. At $48 \mathrm{hr}$, a mean of 6.0 were on the surface, and two of the total 40 were dead. At $72 \mathrm{hr}$, the mean number of Stylodrilus dead on the surface had increased to 8.4 per replicate, and the remaining mean of 1.3 worms per replicate on the surface appeared nearly dead. The experiment was stopped at the end of $72 \mathrm{hr}$; only six of the initial total Stylodrilus were alive, none of which appeared healthy.

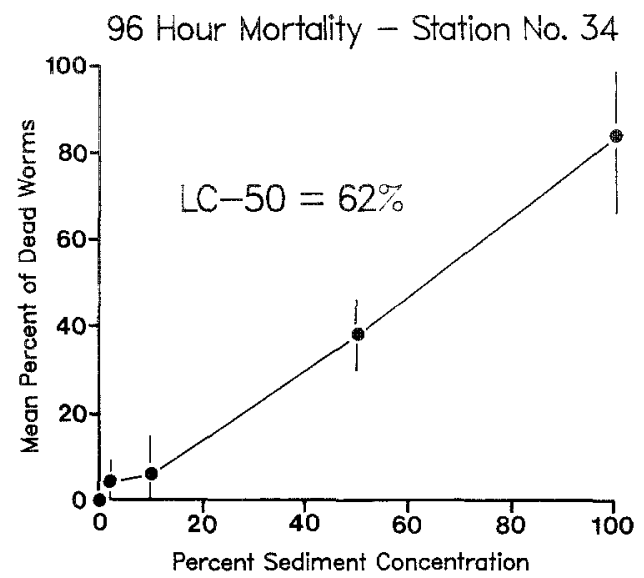

Fig. 8. Mean percent and standard error of Stylodrilus mortality at the end of $96 \mathrm{hr}$ in 5 concentrations of Station 34 sediments diluted with Lake Michigan (control) sediment (v:v), 5 replicates, 10 worms per replicate

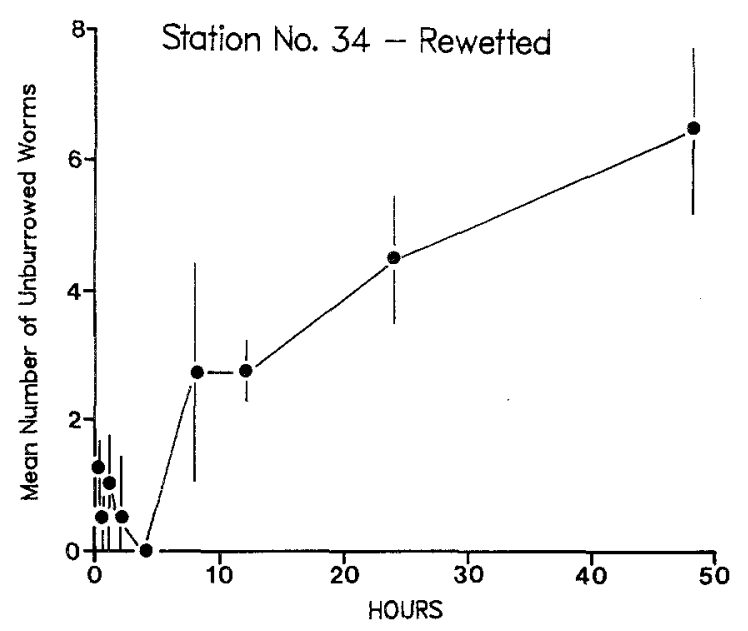

Fig. 9. Mean number and standard error of unburrowed Stylodrilus over time in the first $48 \mathrm{hr}$ of the 72 -hr assay using dried and rewetted sediment from Detroit River Station 34, 4 replicates, 10 worms per replicate

\section{Burrowing and $E C_{50} / L C_{50}$ Patterns}

A variety of burrowing patterns were noted in the sediment assays along with differences in mortality. Combining these data with data from Keilty (1987) and Keilty et al. 1988, we have attempted a first assessment of burrowing/mortality patterns in relation to potential sediment contamination (Table 2). Based on Table 2, sediments from Station 83 would be judged non-toxic to Stylodrilus, i.e., levels of metals or toxic organics, if present, were not great enough to stimulate burrowing pattern changes within 96 hr. No mortality occurred in Station 53 
Table 2. Levels of sediment contamination as determined from the Stylodrilus heringianus burrowing avoidance assays for Detroit River sediments and for data from Keilty (1987) and Keilty et al. (1987). Numbers based on 10 worms per assay replicate.

\begin{tabular}{|c|c|c|c|c|}
\hline \multirow[b]{2}{*}{ Level of contamination } & \multicolumn{4}{|c|}{ Mean number of worms on surface } \\
\hline & $\begin{array}{l}\text { Beginning phase } \\
2-8 \mathrm{hr}\end{array}$ & $\begin{array}{l}\text { Ending phase } \\
48-96 \mathrm{hr}\end{array}$ & $\begin{array}{l}\text { \% Mortality } \\
96 \mathrm{hr}\end{array}$ & $\begin{array}{l}\text { Detroit River } \\
\text { Station }\end{array}$ \\
\hline Uncontaminated & $<1.0$ & $<1.0$ & $<1.0$ & $\begin{array}{l}\text { Control } \\
83\end{array}$ \\
\hline \multicolumn{5}{|l|}{ Sediments alone } \\
\hline Mild contamination & $<1.0$ & $1.0-2.0$ & $<1.0$ & 53 \\
\hline Moderate contamination & $<1.0$ & $2.0-5.0$ & $1.0-5.0$ & \\
\hline Strong contamination & $<1.0$ & $>5.0$ & $>5.0$ & \\
\hline \multicolumn{5}{|l|}{ Sediments and pore water } \\
\hline Mild contamination & $1.0-5.0$ & $1.0-5.0$ & $<5.0$ & 30 \\
\hline Strong contamination & $>5.0$ & $>5.0$ & $>5.0$ & 34 \\
\hline
\end{tabular}

sediments. All Stylodrilus burrowed in the beginning phase, but a mean of 2.0 worms per replicate were unburrowed at $96 \mathrm{hr}$, indicating a mild response, probably due to sediment-bound contaminants. In Station 30 sediments, there was a slight burrowing response in the beginning phase and a high burrowing response in the ending phase, with increased mortality toward the end of $96 \mathrm{hr}$. This may represent some initial response to pore water contaminants and then a reaction to more tightly bound contaminants.

Station 34 sediment assays yielded strong beginning and ending phase responses and $94 \%$ mortality. Responses in the beginning burrowing phase were eliminated by drying and rewetting, suggesting that volatile or pore water contaminants initially present in Station 34 sediments, which acted as an external irritant deterring burrowing, were reduced. However, because Stylodrilus returned to the surface and died after the beginning phase in rewetted sediments, the lethal response-producing contaminants apparently were bound to sediments or present in the overlying and pore waters in a non-volatile form. This type of assay provides valuable lethal toxicity data which could be used to compare the relative potential toxicity of different contaminated sediments.

Beyond the general responses provided in Table 2 , other behavioral and feeding responses were observed. Normal burrowing and feeding behavior usually resulted in both a mosaic of tunnels through out the sediment, many of which were clearly visible along the sides of the beakers, and in a roughing of the sediment surface (Figure 10). Both tunnels and surface roughing occurred in assays using control and Station 30, 53, and 83 sediments. Although some Stylodrilus did burrow in the first

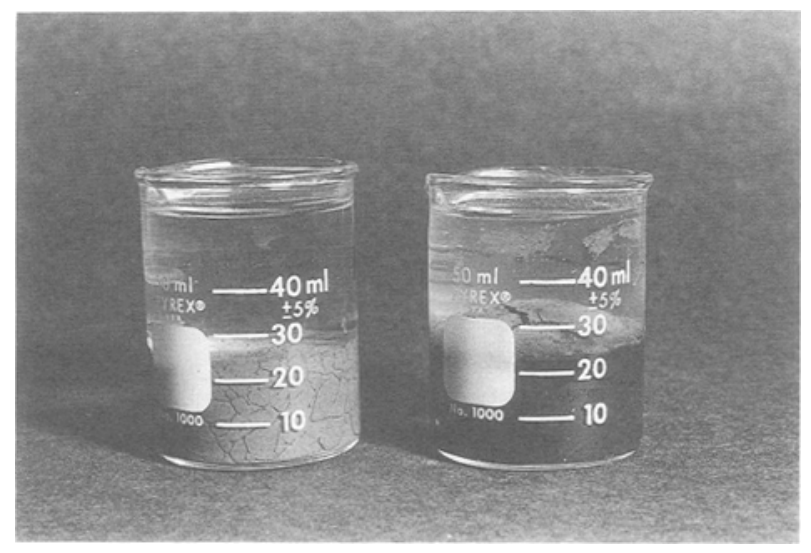

Fig. 10. Photograph of beakers containing Lake Michigan (Control) (left) and Station 34 (right) sediments and 10 Stylodrilus after 96 hr. Note absence of burrows and surface roughing and the dark coloration of Station 34 sediment.

assay of Station 34 sediments, few tunnels were visible, and the surface remained relatively smooth (Figure 10), suggesting that normal feeding activities did not occur. Feeding channels were present in the rewetted 34 sediment assay, leading to the conclusion that mortality was most likely caused by ingestion of bound or pore water contaminants remaining.

Tubificids are often pictured with their tails protruding some distance above surface fecal mounds (e.g., Mozley and Howmiller 1977; White et al. 1986a). Although we have occasionally observed this behavior, a large proportion of the individuals of most Great Lakes tubificid species and Stylodrilus remain entirely beneath the sediment surface, except to expel an occasional fecal pellet. In our assays, the classic tail protruding behavior was observed only in response to apparent sediment 
contamination. Prior to returning to the sediment surface, about $25 \%$ of a worm was exposed as in the classical description, which occurred anywhere from eight hr (rewetted Station 34 sediments) to 72 $\mathrm{hr}$ into the assay (Station 53 sediments) and lasted up to $24 \mathrm{hr}$. Both the extent of visible channels and first stage of the 'unburrowing' process are potential additional response variables to be considered in future assays.

\section{Comparisons With Natural Detroit River Populations and Trophic Indicators}

At least a few oligochaetes were present in the sediments collected at each study site. Species were limited, however, to those classified as saprophilic and saprobiontic Tubificidae (Lauritsen et al. 1985). Limnodrilus hoffmeisteri and L. claparedianus were present at Station 30 and were collected there at other times of the year (White, unpub. data). A few $L$. hoffmeisteri and $L$. claparedianus were recovered from Station 34, but no worms had been found in any of our previous collections. Only $L$. cervix was found at Station 53, which also was the only species previously collected there. No oligochaetes were found in Station 83 sediments; however, we had previously collected both $L$. hoffmeisteri and $L$. claparedianus. These data corresponded to recent descriptions of the distribution and abundance of oligochaetes (primarily Tubificidae and Naididae) in the Detroit River (Ontario Ministry of the Environment 1979; Hiltunen and Manny 1982; Thornley and Hamdy 1984; Thornley 1985).

$L$. hoffmeisteri and $L$. claparedianus have been classified as indicators of organic enrichment. $L$. cervix is an indicator of heavy organic enrichment, while the presence of Stylodrilus usually indicates extremely low levels of enrichment (Lauritsen et al. 1985). Associations of distributions (particularly for L. hoffmeisteri and Stylodrilus heringianus) with various in-place contaminants are limited (Chapman and Brinkhurst 1984), but in laboratory studies Chapman et al. (1982a, 1982b, 1982c) found that Stylodrilus was often less sensitive (using death as the endpoint) than $L$. hoffmeisteri to a variety of contaminants in water. Keilty et al. (1988), however, found that Stylodrilus was more sensitive than $L$. hoffmeisteri to endrin-contaminated sediments using sublethal behavioral response assays, which is consistent with the proposed trophic status of the two species (Lauritsen et al. 1985). These data suggest that a sublethal assay is more sensitive than a lethal assay. Even though Chapman and Brinkhurst (1984), Lauritsen et al. (1985), and others have questioned the oligotrophic status of Stylodrilus, the results from these tests, along with the fact that some $L$. hoffmeisteri were present in the original sediments, indicate a greater sensitivity of Stylodrilus to Detroit River sediment bound contaminants. Further, the ease of separating Stylodrilus from other live worms (White et al. 1987) makes this an attractive species for bioassay.

Acknowledgments. We wish to thank Morris Flexner, Susan Hendricks, and John Houseal for assistance with the laboratory tests. Photographs were provided by Deborah Sandberg. Personnel of the Large Lakes Research Station, Grosse Ile, Michigan (USEPA) aided in collection of sediments and water. This research was funded by a cooperative grant from the US Environmental Protection Agency (CR812469-01-0). Contribution No. 484 from the Great Lakes Research Division.

\section{References}

Bulich AA, Isenberg DL (1981) Use of the luminescent bacterial system for the rapid assessment of aquatic toxicity. ISA Trans 20:29-33

Chapman PM, Brinkhurst RO (1984) Lethal and sublethal tolerances of aquatic oligochaetes with reference to their use as a biotic index of pollution. Hydrobiologia 115:139-144

Chapman PM, Farrell MA, Brinkhurst RO (1982a) Effects of species interactions on the survival and respiration of $\mathrm{Lim}$ nodrilus hoffmeisteri and Tubifex tubifex (Oligochaeta, Tubificidae) exposed to various pollutants and environmental factors. Water Res 16:1405-1408

- (1982b) Relative tolerances of selected aquatic oligochaetes to individual pollutants and environmental factors. Aquat Toxicol 2:47-67

- (1982c) Relative tolerances of selected aquatic oligochaetes to combinations of pollutants and environmental factors. Aquat Toxicol 2:69-87

Chau YK, Maguire RJ, Wong PTS, Sanderson ME (eds) (1985) Detroit River - St. Clair River special issue. J Great Lakes Res 11:191-418

Comba ME, Kaiser KLE (1985) Volatile halocarbons in the Detroit River and their relationship with contaminant sources. J Great Lakes Res 11:404-418

Hamdy Y, Post L (1985) Distribution of mercury, trace organics, and other heavy metals in Detroit River sediments. J Great Lakes Res 11:353-365

Hiltunen JK, Manny BA (1982) Distribution and abundance of macrozoobenthos in the Detroit River and Lake St. Clair, 1977. Rept 82-2 Great Lakes Fishery Laboratory, U.S. Fish and Wildlife Service, Ann Arbor, Michigan

Keilty TJ (1987) Lethal and sublethal responses to a sediment bound toxicant by two oligochaetes from Lake Michigan: Stylodrilus heringianus and Limnodrilus hoffmeisteri. $\mathrm{PhD}$ dissertation, University of Michigan, Ann Arbor

Keilty TJ, White DS, Landrum PF (1988) Short-term lethality and sediment avoidance assays with endrin contaminated sediment and two oligochaetes from Lake Michigan: Stylodrilus heringianus (Lumbriculidae) and Limnodrilus hoffmeisteri (Tubificidae). Arch Environ Contam Toxicol 17:95101 
LaDronka R (1984) Part 3: Oligochaeta. In: White DS (ed) Ecology of the zoobenthos of southeastern Lake Michigan near the D.C. Cook Nuclear Power Plant. Special Rept 122, Great Lakes Research Division, University of Michigan, Ann Arbor, $214 \mathrm{pp}$

Lauritsen DD, Mozley SC, White DS (1985) Distribution of oligochaetes in Lake Michigan and comments on their use as indices of pollution. J Great Lakes Res 11:67-76

Litchfield JV, Wilcoxon F (1949) A simplified method for evaluating dose effect experiments. J Pharmacol Exp Ther 96:49_ 113

Miller WE, Greene JC, Shiroyama T (1978) The Selenastrum capricornutum Printz algal assay bottle test. Environmental Research Laboratory, US Environmental Protection Agency, Corvalis, Oregon

Mount DI, Norberg TJ (1984) A seven-day life-cycle cladoceran toxicity test. Environ Toxicol Chem 3:425-434

Mozley SC, Howmiller RP (1977) Environmental status of the Lake Michigan Region, Vol. 6, Benthos of Lake Michigan. Argonne National Laboratory ANL/ES 40, Argonne, Illinois, $48 \mathrm{pp}$

Mudroch A (1985) Geochemistry of the Detroit River sediments. J Great Lakes Res 11:193-200

Oliver BG, Bourbonniere RA (1985) Chlorinated contaminants in surficial sediments of Lakes Huron, St. Clair, and Erie: Implications regarding sources along the St. Clair and Detroit Rivers. J Great Lakes Res 11:366-372

Ontario Ministry of the Environment (1979) St. Clair River organics study-biological surveys, 1968 and 1977. Ontario Ministry of the Environment, London, Ontario, Canada

Robbins JA, Husby-Coupland K, White DS (1984) Precise radiotracer measurement of the rate of sediment reworking by
Stylodrilus heringianus and the effects of variable dissolved oxygen concentrations. J Great Lakes Res 10:335-347

Thornley S (1985) Macrozoobenthos of the Detroit and St. Clair Rivers with comparisons to neighbouring waters. I Great Lakes Res 11:290-296

Thornley S, Hamdy Y (1984) An assessment of the bottom fauna and sediments of the Detroit River. Ontario Ministry of the Environment Report, London, Ontario, Canada

White DS (1988) Persistent toxic substances and zoobenthos in the Great Lakes. In: Evans MS (ed) Great Lakes ecosystems health: Effects of toxic substances. John Wiley \& Sons, New York, (in press)

White DS, Winnell MH, Zawacki CM, LaDronka RM, Zdeba TW, Mozley SC (1986a) Ecology of the zoobenthos in the nearshore of southeastern Lake Michigan in the vicinity of the D.C. Cook Nuclear Plant studies. Special Publication 22, Great Lakes Research Division, University of Michigan, Ann Arbor, pp 206-261

- (1986b) Effects of the D.C. Cook Nuclear Plant on zoobenthos in the nearshore of southeastern Lake Michigan. In: Rossman R (ed) The D.C. Cook Nuclear Plant studies. Special Publication 22, Great Lakes Research Division, University of Michigan, Ann Arbor, pp 262-291

White DS, Klahr PC, Robbins JA (1987) The effects of temperature and density on sediment reworking by Srylodrilus heringianus (Oligochaeta: Lumbriculidae). J Great Lakes Res $13: 147-156$

Manuscript received September 16, 1987 and in revised form January 9,1988. 